\title{
HERDING SPECIES: Biosecurity, Posthuman Labor, and the American Industrial Pig
}

\section{ALEX BLANCHETTE \\ Tufts University}

In the late spring of 2013, Porcine Epidemic Diarrhea virus (PEDv) first emerged on the Great Plains and swept through North American hog herds. Within a year, it had taken a toll of some seven million animals, or 10 percent of the pigs in the United States (Eisenstadt 2014). One of the disease's rumored ground zeroes was near the factory farms where I had previously conducted twenty-four months of ethnographic research, tracing the making of the industrial pig across all stages from prelife to postdeath. Moving across this multistate region on the Great Plains, the disease would hop over the Midwest's pockets of concentrated porcine life that stretch all the way from rural Missouri to Utah. ${ }^{1}$ I returned shortly after the first outbreak, as alarmed rumors were circulating that the town's slaughterhouse might shut down. In its first wave through Dover Foods' animals, PEDv exhibited a near-100 percent piglet kill rate. A friend who worked for this pork corporation — one of the world's largest - grimly recounted how they had lost some 190,000 piglets in that week alone. Across the United States, the sheer amount of diseased pig carcasses became a source of environmental risk, the seepage from mass burial sites threatening groundwater (Strom 2014). Traveling via aerosolized manure over a still-uncertain number of miles, PEDv left few of Dover Foods' 1,400 confinement barns unaffected. In areas such as this one-a hundred-mile radius region where some seven million pigs are annually raised and killed_ contact with the virus has become almost unavoidable. 
For example, a recent study describes how floors from fifty convenience stores in rural pork-intensive Iowa were swabbed for PEDv. They all returned positive for the disease (Thaler 2013). For those initial weeks of the outbreak, at least, PEDv dramatically changed the tenor of farm labor from forcefully maximizing life to solemnly caretaking death. An acquaintance told me how her son, who worked in farrowing (the delivery of piglets), was returning home in tears. His days were a blur of pushing full wheelbarrows of small corpses into dumpsters. As I visited breeding farms, the acrid smoke of black incinerators saturated the summer air.

Yet the present urgency of containing PEDv_ framed by the pork industry as a foreign disease agent that appeared out of nowhere - elides more quiet crises of reproduction that have long been endemic to the factory farm's routine operations. Prior to PEDv's appearance in the United States, far-reaching but mundane, almost unnoticeable biosecurity regimes were deemed necessary to maintain porcine proliferation. And these modes of corporate governance, developed through porcine vitalities, subtly redefine what it means to be human for those who work in a world saturated by concentrated animal life. In response, this essay will chart a political economy of speciation - a critical articulation of the making and ranking of species - to analyze how an ambiguously postanthropocentric politics of class and value is emerging in pockets of the rural United States organized around fragile capitalist life forms. In so doing, my aim is to describe how we can grasp the factory farm as a project that — in spite of being built to take animal livescomes to reverse the typical hierarchy of species and attempts to confine people in porcine worlds. The story begins near the end of my workplace-based research, when I first sensed the microbial textures that invisibly surrounded me, jolting my assumptions about the forms of routine labor and subjectivity that underlie the industrialization of the American pig.

I was standing with my coworker, Cesar, in the corner of a barn's concrete workshop as he took a cigarette break after working the artificial insemination line of a 2,500-sow breeding farm. This one barn alone births almost one thousand piglets per week for a pork corporation called Berkamp Meats, one of Dover Foods' regional competitors. Cesar carefully balanced on the ridges of a door frame while making sure his sanitized black rubber boots did not come into contact with the outside dirt surrounding the barn. His posture exhibited traces of the biosecurity-based discipline we learned in training, hinting at his tacit biological proximity to the animal (see Shukin 2009). As we casually discussed his life as a migrant to the United States, Cesar pointed his blue latex-covered hand outside 
at a white truck that veered over the gravel roads around the dozens of hog barns on the horizon. He guessed his father or brother were passengers. They formed part of the itinerant medical crews that visited dozens of hog barns every day, checking on the status of automated feeders while injecting vaccines and antibiotics into growing animals after they left breeding barns. Making idle chatter, I asked if his whole family worked for Berkamp. He shrugged: "Me and my family, we have no choice because of biosecurity." ${ }^{2}$

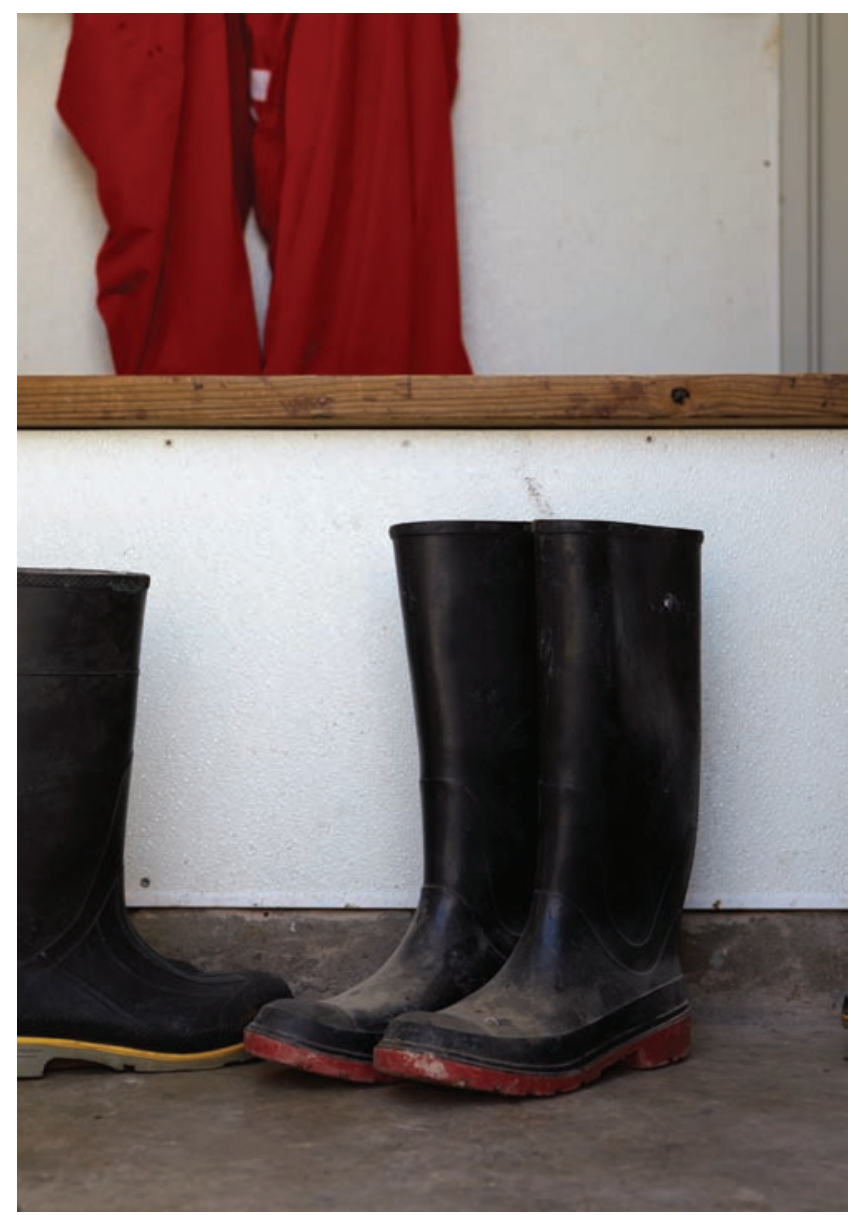

Figure 1. Company-supplied boots and coveralls. As part of biosecurity protocols, farm employees shower at each worksite and wear laundered uniforms. Photo by Sean J. Sprague.

Originally from Guatemala, Cesar had migrated with his parents and siblings to the Great Plains around 2000, when he was in his early twenties, after hearing of gainful employment in slaughterhouses, on hog farms, and at feed mills. Sharing 
a trailer on the outskirts of town, the family plugged into the large K'iche'speaking community and eventually found work on Dover Foods' breeding farms. In so doing, they joined a workforce of four thousand migrants - from twentysix different language backgrounds - whose invisible labor underlies the massproduction of life. The family worked on Dover Foods' sow farms for years, increasing their experience, until Berkamp offered Cesar's father a supervisory position in the company. But there was a significant catch: on learning this news, Dover's managers insisted that Cesar and his siblings must either live separately from the father or that all the children would have to quit and find work with another company.

Managers at Dover Foods were concerned that microscopic particles of hog saliva, blood, feces, semen, or barn bacteria from another company, or from another stage in Dover's own meat production process, might get lodged in workers' ears, fingernails, and nostrils despite worksite-mandated showering protocols. ${ }^{3}$ The corporation's theory was that prolonged physical proximity between workers - across firms and across farms - could result in disease transferring over human bodies and, in turn, rippling through untainted barns of swine. A few years earlier, managers had allegedly started monitoring addresses on payroll forms to map overlaps between regional domestic living arrangements and the corporation's division of labor across its vertically integrated network of boar studs, sow farms, growing barns, feed mills, and slaughterhouses.

Intrigued, I inquired with employees in an ESL class and after church events in the town of Dixon, a small and at times tight-knit rural community of some fifteen thousand people that is home to Dover Foods' central slaughterhouse. Many residents shared a similar story of how biosecurity subtly disrupted their lives. For example, a newlywed was disappointed that she had to abandon her job at a Dover breeding farm. She took pride in caring for newborn piglets, but she had to quit because her husband held a monotonous yet better-paid position cutting meat on the slaughterhouse disassembly line. Another maintained an old mailing address since he worked as an assistant manager in nursery barns for young pigs, while his new roommates were in breeding. There was little overt outrage directed at these protocols. More often than not, people expressed a shrug of befuddlement as to why they existed. But these stories have stuck with me, for they suggest subtle changes in terms of how agribusinesses are coming to understand the nature and needs of the industrial pig.

Even more striking were the ways that senior managers were not immune to the social repercussions of their own biosecurity protocols. At an anniversary 
party for Dover Foods, a slaughterhouse manager felt frustrated that he barely recognized the faces of his colleagues from the "Live Side" of the company. He knew them primarily as names on a spreadsheet because, he claimed, principles of biosecurity suggested that the two sides should not socialize outside work except on these rare occasions. ${ }^{4}$ Managers such as this one appeared to be living out protocols even stricter than those imposed onto workers. This man was anticipating and modeling his sociality on an imagined future where public space beyond the domestic household — such as bars, churches, or clubs - is biosecure. The vertical integration of the hog - controlling all phases of the species' life and death, while creating specialized sites and organization for each type and age of pig-was spawning forms of social reorganization as the corporation mapped outof-work human relations onto the fissures of industrialized animal life cycles, creating microbiopolitical ruts in regional circuits of sociality (Paxson 2008).

The result is a region where both managers and workers - albeit in profoundly unequal ways, each with different relationships to the industrial hogare induced to consider their relation to a form of life that redefines people, wind, and terrain as carriers of disease threatening the productivity of breeding stock. Over the years, I have read many scholarly studies and journalistic exposés of factory farms that describe how manure-laden winds and nitrogen-loaded wells degrade quality of life in surrounding communities (e.g., Thu and Durrenberger 1996; Kirby 2010; Genoways 2014). The neighbors interviewed in these writings suggest how pork production remains porous, drawing our attention to the shared mediums - air and water - that continue to bind pigs and people in spite of the animals' confinement indoors. But biosecurity here requires another kind of attention to the invisible copresence of the pig in everyday life, a different kind of multispecies atmospheric attunement. ${ }^{5}$ Since its founding as a global locus for hog production in the mid-1990s, this region has become a zone that locals describe as one of the "red meat capitals of the world," where hogs outnumber humans by more than fifty-to-one. In this context, Cesar's story hints at how a concentrated form of porcine life swells across the region, microscopically saturating human bodies, while potentially buttressing novel forms of discipline and consciousness of one's relation to surrounding ecologies, kin, and socialities. His story depicts a place where efforts to sustain the waning vitality of the industrial hog are provoking the industrialization of many other forms of social and biological life that exist in this animal's ever-expanding orbit.

Granted, industrial extension beyond the factory floor is not new. ${ }^{6}$ Feminist social scientists have long shown the dynamic ways that domestic households and 
unwaged work are intertwined in the reproduction of capitalist industry. The household has always been essential to the (re)production of labor power, socialization, and the very meaning of wage labor (see Rubin 1975; Weeks 2011). Similarly, efforts to rationalize laborers' domestic sociality for the improvement of workplace morale date back to Fordism's founding moments. Henry Ford's Sociological Department infamously inspected employees' homes, hygiene, and spending habits in exchange for earning the five-dollar day (Meyer 1981). Yet biosecurity, in this instance, is not about biologically or socially reproducing human labor power. Nor does it form part of a humanist industrial morality, of creating the ideal (white, male) worker who can stand on and withstand the assembly line. Instead, these interventions into human spheres are premised on reproducing animal reproduction. They suggest an imminent orientation where the value of routine action - from showering at home to sharing a bottle of wine in a park - could be indexed and appraised in terms of its potential effects on pigs' numerical proliferation.

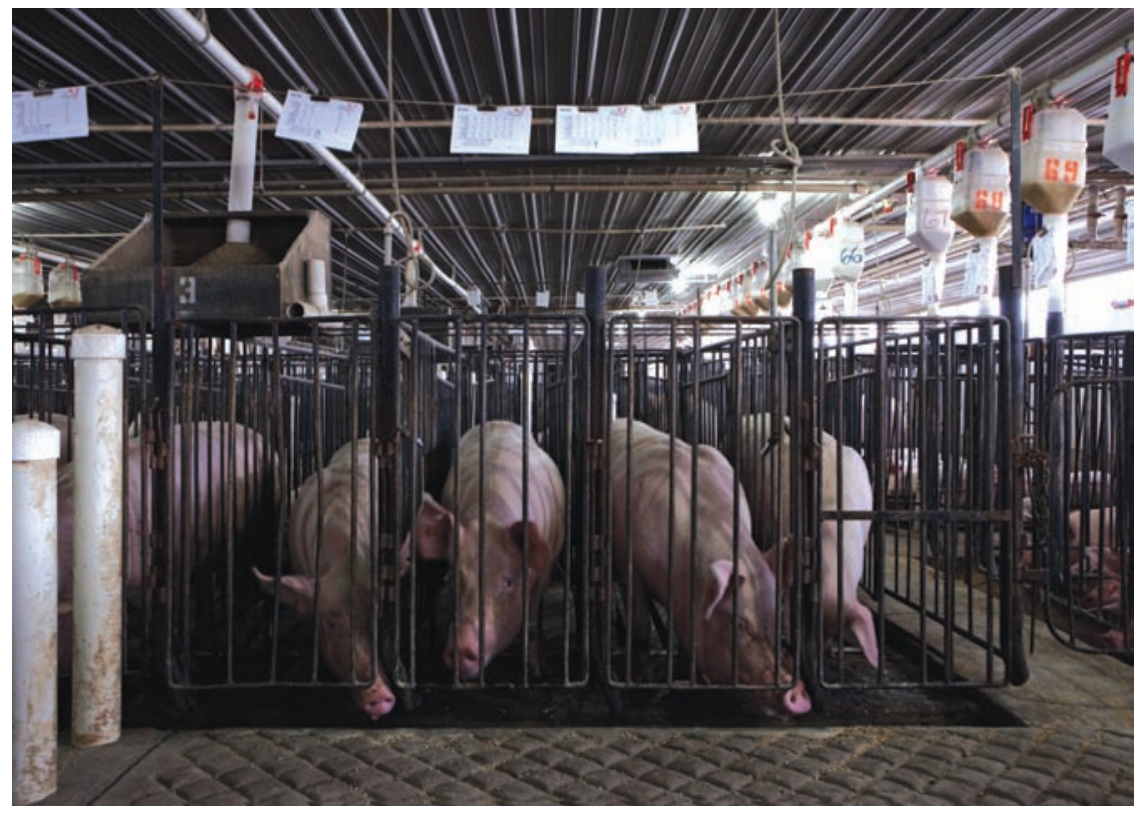

Figure 2. Breeding sows in individual gestation crates. Photo by Sean J. Sprague.

Much recent scholarship and political commentary probes possibilities for renewing life in the Anthropocene, of finding ways to coexist with beings beyond the human. On the one hand, we could continue to practice the fantasy of human 
exceptionalism by pretending it is possible to maintain a pure separation between human and "animal” worlds (Raffles 2010, 330). As Celia Lowe (2010) articulates in a study of avian flu's viral (dis)entanglements, agricultural biosecurity figures as a central site for generating (impossible) anthropocentric ideals of rigorously ordered, perfectly planned, and purely human biosocial worlds. On the other, a broadly more-than-human scholarship has taken up the urgent political task of opposing such narratives of disembodied and autonomous human omniscience by articulating how species are relationally entangled at their core (Nading 2012; Porter 2013), living with and making each other up in interactive everyday flow (Haraway 2008; Kohn 2013), and shaping each other in codomesticated exchanges across deep history (Cassidy and Mullin 2007; Tsing 2012). But projects like the factory farm - seemingly a straightforward site of human domination - suggest the need for still another approach. These anthropocentric projects, to the extent that they revolve around satisfying human diets and livelihoods by taking the lives of other species (Wolfe 2012), conjure fantasies of an ahuman landscape. Such fantasies are not an idiosyncrasy of industrial hog production. Similar tendencies are visible in the body-breaking, pesticide-laden fruit farms of the U.S. West Coast (Holmes 2013), amid Paraguay's deathly soy fields (Hetherington 2013), and from the factory farm itself as a key contributor of greenhouse gas emissions (Weis 2013). Industrial agriculture is manufacturing cheap food for human consumption by overtaking swathes of territory in ways that prioritize the value of its singular organisms over other forms of life. ${ }^{7}$

What Cesar's seemingly innocent family story suggests, then, are the ways that the working human, in both its social and embodied aspects, is becoming suspect. This, too, is not necessarily new. The farm laborer's body has recently emerged as a site of risk in public health studies that fret about its ability to carry antibiotic-resistant bacteria off farms (Nadimpalli et al. 2014), or how it could serve as a transmission point for zoonotic swine influenza viruses (Gray et al. 2007). But what is jarring about this postanthropocentric biosecurity protocol is its reversal of the typical ranking of species. Human labor is framed as a threat to industrial pork - albeit, at this moment, a necessary one given that machines cannot raise hogs alone - and it is the industrial pig whose vital safety requires intervention. This constitutes the reverse of the standard anthropocentric fears of public policy, such that wild animals' suspect movements or leaky bodies will come to infect human populations through zoonotic illness (Davis 2007). The indoor confinement of farm animals is itself often justified in the face of the viral threat of unpredictable contact with beings such as wild geese, whose risky bi- 
ologies make for key natural reservoirs of zoonotic disease (Fearnley 2015). Instead this rural space, which is given over to making industrialized organisms, suggests how the laboring body and its unpredictable rhythms is engulfed by porcine illness in such a way that human sociality is now marked as the central virtual reservoir sheltering porcine disease. This reversal marks a zone where the protection of the porcine species is broadly privileged over the cultural lives of the corporation's four thousand employees, in spite of individual pig bodies being radically killable as a nondescript biomass in the slaughterhouse. Or, more precisely, such securities suggest an avowedly biocapitalist landscape whereby individual porcine lives may be expendable as cheap meat, but intensifying the generative potentials of swine as a species - the vital processes of birth and growth (Helmreich 2008) — trumps classic humanist ideals of autonomy, freedom, and privacy. This distinction between individual hogs and the porcine species, in turn, is the ground on which corporations are remaking classes of people.

This essay follows the foundational lead of scholars who have developed ethnographically specific ways of framing how vital governance extends across species, and how people are made to "work on [themselves] in relation to" other, often anthropogenically weakened beings (Porter 2013, 144). What intrigues me about the factory farm's intimate biosecurities is how they mark an attempt to convert personal or private actions that seemingly have no bearing on others, such as looking for an apartment, into what we might label a posthuman form of labor in the service of maintaining industrial porcine life. Such emerging subjectivities in the factory farm suggest a managerial-capitalist zone where the value of routine or previously unnoticed human activity is increasingly measured by how it is taken up by, and expressed in, other kinds of animals. There are many ways that one might develop the notion of posthuman labor, extending the discourse of posthumanism - which aims to decenter humanity as the bearer of autonomous value and uniqueness in the world (Wolfe 2009) - into a type of practice. These might involve theorizing how nonhuman beings can also be said to "work" (White 1995), recognizing distributed worldly agencies such that humans never labor with other humans alone (Bennett 2010), critiquing the exceptional value of human labor (Weeks 2011), or paying attention to how artists and activists work to reveal interspecies entanglements (see Kirksey 2014). In this essay, however, my aim is not to develop a philosophical posthumanism that critiques liberal capitalism from outside, but instead to trace how this sensibilityhowever disfigured or co-opted - manifests itself in capitalist practices. For the site of the factory farm does not so much call for an effort to positively decenter 
the human as it requires us to grasp the work - especially that of managerswhich enables the porcine species' vitality to mediate a region. This perspective enables us to see interspecies power relations anew, and it has consequences for how we interpret the founding myth of industrial agriculture as an efficient organizational form that uses less land and labor to feed the world.

How, then, did the industrial pig come to embody a regionally exceptional status; how did this animal species become the central optic through which regional human action is potentially appraised? How did the pig become such a fragile organism, both in terms of its physical frailty and of agribusiness's perception of its weakness, while at the same time it is so privileged and worthy of protection? What, in short, is the shifting industrial pig (as opposed to the timeless natural pig) as a form of life? Rather than reducing posthuman labor to an automatic outgrowth of biocapital or the commodity form, the remainder of this essay follows managers as they construct the pig as a world-defining creature that quietly overdetermines the lives of regional residents (cf. Sunder Rajan 2012 on overdetermination). In describing this political economy of speciation, I am appealing not to the classic taxonomical definition of species in terms of reproductive capacity and difference, much less searching for a stable essence of pig and human in a context where these beings mutually (re)constitute each other. ${ }^{8}$ Instead, I trace managers' ongoing efforts to know and inhabit the porcine species in its totality, even as they rank and remake classes of people through this pig.

\section{THE EXPANDING BOUNDARIES OF THE HERD}

Managers have learned to intervene in the Great Plains' saturated microbial ecology by analyzing how it becomes statistically indexed to the bodies of breeding stock, using an organizational technology they call the Herd. ${ }^{9}$ The Herd is invisible outside of spreadsheets, computer tabulations, scroll charts, or other abstract representations. Yet it productively mediates managers' experience of not only the industrial pig, but also of surrounding socio-ecologies from trucking routes to wind patterns. In practice, the Herd operates as a species-making device - a means for managers to abstract from the material, embodied expressions of individual porcine lives or types such as boars, sows, or piglets. Treating their pigs as a Herd, as I will show, is what makes managers into proper managers of vertically integrated life. A worker in the boar stud experiences only boars, a person in finishing barns works only with grown meat hogs, and a given employee on the cut floor might interact with thousands of left hams every day. ${ }^{10}$ Senior managers, by distinction, are the only people in the factory farm who can work 
across all manifestations of the pig; the Herd is an organizational device that helps them work on the totality of the species.

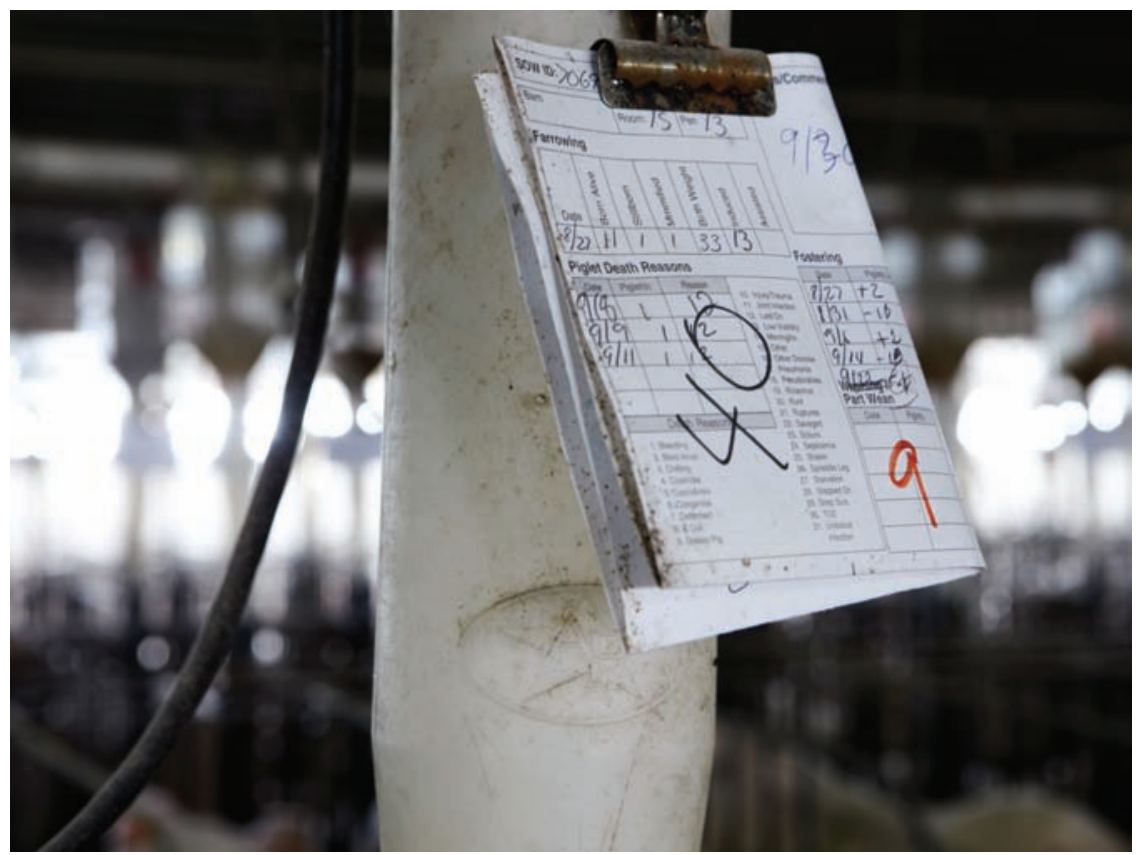

Figure 3. Identification cards on farms identify the breeding performance of a given animal. This information is relayed to administrative offices to provide data for developing a numerical portrait of the Herd as a whole. Photo by Sean J. Sprague.

The Herd is a complicated icon for the factory farm as a whole. It is at once a rationalization for the rise of factory hog farms, a class-based mode of grasping the porcine species as a singular whole, and, in turn, one that helps form regional classes of people through their relation to hogs. At its simplest, the Herd turns Dover Foods' 180,000 breeding animals_-which annually produce five million 285-pound market hogs - into a statistically derived unit of life that is used to appraise the status of the total factory farming process at a given point in time. Such a status, expressed as the "Herd Health," is signaled through measures of the breeding animals' average productivity in terms of pig output. Depending on the position from which it is articulated - say, voiced from a growing farm versus a slaughterhouse - Herd Health might relate to either the average amount of pigs or pounds of meat produced per sow per year. Once forming this virtual meansow, the most senior managers spend their days inspecting material and microbial factors in farms that are producing starkly less (or more) than the rest of the 
Herd. But the Herd, as I will argue in some concluding notes, is also a powerful means of forming species to achieve disciplinary control — and perhaps foreclosing more complicated ethics — not only over disease-ridden ecologies created by the factory farm but also over the moral character of farm laborers.

"The old farming mentality was to manage individual pigs," one senior manager named Barry memorably stated over drinks. "But our mentality is that we manage the Herd. . . . The old farmer used to like some boar or sow and he'd say, 'That's a good animal, I'm gonna keep it." Dover Foods did not favor any animals, he went on to explain, instead grasping high-performance sows as part of "natural variation." They cull and replace their genetic stock of breeding animals at regular intervals of age or litter sizes regardless of a given animal's history. Rather than managing single pigs, then, they articulate themselves as managing abstracted genetics and probability across the whole of the breeding stock. ${ }^{11}$ The Herd is a matter of managing the species as a single mean-sow that is conceptually standardized, even if individual sows vary in productivity. In this sense, we might initially read the Herd as an industrial abstraction, because it enacts a conceptual negation of productive differences across sows by making them disposable and interchangeable in farm practice (see Braverman 1974).

But if the Herd is a quantitative figure for making sense of epochal shifts in pork production, it also operated in managerial circles as a discursive term for establishing managers' own identity and, in turn, tethered regional class difference to how people relate to animals. Senior managers repeated an identical stock phrase whenever I asked them to define their role: "We work on the Herd," they would claim, "while hourly employees and farm managers work with the Herd." Such a proposition of identity does capture a felt reality, especially for senior managers whose daily experience with pigs is in statistical, sampling, tour-based inspection, or paper-based forms. But what interests me is the blurring of difference in the oppositional identity — a seaming of human labor and hog life - once senior managers narrate from the position of working on the Herd as a whole. "Working on" the Herd is best translated as improving the quantitative output of all the breeding animals, irrespective of given animals' qualities. This can make everything from the animals' feed regimen to workers' actions become a legible input toward improving the total Herd. We can glimpse in this stock phrase how the boundaries of the Herd are open; the Herd is a mode of reading a territory through the lens of the porcine species in such a way that it incorporates everything from microbes to terrain to human bodies. And without access to the category and attendant practices of working on the Herd as an abstract species 
whole across workplaces, workers can only relate to (or "work with") animal beings through experiences with concrete manifestations, stages, and specific types of hog life such as boars, sows, piglets, grown pigs, or carcasses. In other words, social class (and race) become regionally mediated through the type and scale of animality that people can sense and inhabit. ${ }^{12}$

Efforts to monitor this region's socio-ecological landscape through the Herd thus differ from what biosecurity has tended to signify in anthropological theories and human-centered situations that problematize it as a virtual or future-oriented trope of governmentality, technoscience, and health planning (see Lakoff and Collier 2008; Caduff 2014). Biosecurity here forms a more banal present-tense, enacted regime of corporate governance, alongside a subtly inculcated ethic for living amid industrial animals. While its implied consequences may be significant, it is rarely remarked on in everyday life. Indeed, if a resident was not employed by these corporations, he or she might not know the protocols even exist. The Herd is a quiet matter of sustaining porcine life amid regional microbial degradation, rather than a robust preemptive transformation of the social contract in anticipation of a catastrophic state of crisis such as a bioterror attack (see Cooper 2008; Lakoff 2008). And since the pig diseases that these biosecurity protocols address do not affect human health — and, unlike in Sarah Franklin's (2007, 174) analysis of the similarly innocuous foot-and-mouth disease, they do not impact international trade and the global circulation of meat - the state and its public health apparatuses are not present. Indeed, while the latter, under the auspices of a One Health approach, often struggles in the face of anthropocentrism to "incorporate the well-being of non-human animals in the purview of [public] health policy" (Lezaun and Porter 2015, 101), the value of human livelihood in the factory farm is subordinated to the porcine species, and it is the unruly social lives of laboring humans that must be monitored to protect porcine proliferation.

Absent the all-or-nothing public imperative of protecting human life from zoonotic infection, these private biosecurity protocols are often framed by managers as mere economic inputs subject to ethically innocuous cost-benefit analyses as to whether they achieve returns in terms of breeding animal productivity. ${ }^{13}$ But not everyone saw such protocols as justifiable ways of comprehending the improvement of animal life. Many managers at competing companies steadfastly refused to enact the domestic protocols. As one explained:

I favor a commonsense approach. I don't think we should be worried about what people are doing when they aren't at work. It's, it's . . . intrusive. I 
mean, we know that PRRS [a particularly rampant hog virus] can travel in wind for three miles and we've got a lot of pigs here. What's next? Trucks spraying the air all over town? Will we put foot baths [iodine buckets] at every gas station entrance and make people disinfect their boots? Where does this end?

This manager is describing future techniques for disciplining the region's ecology, which requires expanding securitization of the Great Plains once managers open the Pandora's box of moving biosecurity beyond the barns. He makes a simple moral claim, one premised on a classic agricultural biosecurity that aims to exclude disease from barns (Allen and Lavau 2015, 347). As private businesses, he states, pork companies should manage pig disease on the confines of their own farm property. He projects an imminent future of biosecurity interventions run amok where working country and residential town collapse together via the circulation of pig disease. At the same time, though, this manager's refusal to enact the protocols in his company highlights that this is not a finished project, a totalized form, or an inevitable future; Great Plains biosecurity remains actual and virtual (Collier, Lakoff, and Rabinow 2004, 5). On the one hand, unlike large-scale, purely anticipatory biosecurities, it forms part of an everyday infrastructure - a routine regime, however incomplete. On the other, I noted how some workers refuse these biosecurity protocols, and how some managers themselves enact interventions more extensively in their own lives than they do in those of their employees. From church gatherings to birthday parties, from sharing a fork to sitting on a sofa with a coworker, there are as many potential bio-insecure spaces in this region as there are social relations. Yet as the manager here suggests, such is the power of the Herd's expanding boundaries, signaled by arrangements like the domestic housing biosecurity protocol. Once enacted, such arrangements can illuminate the multitude of bio-insecure practices that stand to impact the pig. ${ }^{14}$

\section{A GREENFIELD}

The situation was not always like this. Elements of the Great Plains' natural ecology initially attracted companies to the region, hoping its relative dearth of precipitation and deep groundwater could mitigate ecological concerns with respect to waste management emerging out of North Carolina in the 1990s, which was the first region in the United States to experience the growth of new industrial hog farms. North Carolina was addled with hurricanes that caused dramatic overflowing of concentrated manure lagoons. Witnessing the public outcry that en- 
sued, corporations - from North America, Western Europe, and East Asiashifted their focus for new pork development to parts of the U.S. Midwest. They were drawn by the region's moderate temperatures, higher evaporation rates that eased how often they would need to apply manure from the lagoons onto surrounding fields, sharp winds that blow lingering smells onto neighboring property, and the availability of grain-based feed. Moreover, economically depressed counties offered tax breaks and other incentives for feed mills, barns, and slaughterhouses to decrease the cost of construction, while many states have adopted "rightto-work" laws that limit the efficacy of labor unions. By the late 1990s, corporations were reshaping the animal ecologies of the rural Great Plains - from Missouri to Manitoba, and from Nebraska to Texas.

But the crucial attraction for corporations to the Great Plains - at least outside of the traditional hog belt that extends from Iowa to Minnesota - was its scarcity of pigs. In 1993, for example, one of the counties that forms part of this study annually produced only a few thousand hogs. By 2010, it would annually raise and slaughter millions of animals. The lack of hogs on the landscape proved crucial for two reasons. The first was the near-total absence of swine disease in the microbial ecology, an advantage that has clearly diminished during the past twenty years. But the second was the concurrent lack of independent hog farmers contracting to raise pigs, the standard form of risk-sharing and horizontal integration in the corporate pork industry (Rich 2008). ${ }^{15}$ This enabled these corporations to attempt full vertical integration by purchasing the land and buildings themselves, operating entirely on the labor of migrant workers who were said to have little background in agriculture.

As Dover's CEO recounted in an interview, the company was "a start-up, a greenfield," where "we could design a core system from scratch." Greenfield is business-speak for underdeveloped territory, marking a vision of this region as pure in its absence of pig disease, pig farmers, or preexisting claims on the land. The result of this frontier-like agricultural space was a series of experiments. One company imported managers from across the globe-including Ukraine, Japan, Russia, and South Africa - to pool global swine knowledge. Others installed barns with cutting-edge technologies such as (relatively) ecologically benign manure composting, or electronic sow feeders that deliver precise quantities of food read off computer chips implanted into animal ears. Dover Foods created a closedloop network of industrialized hog energetics; their system now includes 1,400 barns, feed mills, one of the world's most advanced slaughterhouses, and a series of value-added ventures that recycle blood from slaughtered pigs into plasma for 
piglet diets, or manure into biogas to power the slaughterhouse. They developed a company region economically and socially constituted by industrial pigs.

\section{THE AGING OF THE HERD}

On a midsummer Monday, I was waiting under the black 3:30 a.m. sky for my management guides to arrive in their company-branded van. For months, I had been shadowing managers from various stages of porcine life across their routine working days and joining them in evening classes on Japanese manufacturing theory designed to rethink the "biological system" (their words) of pork production. On this day, we would be driving out to a boar stud facility where collections begin at 5 a.m. to ensure a steady supply of semen for morning inseminations on sow-breeding farms. Since many of the most devastating pig diseases are communicable through the semen that underpins and conjoins (sow) breeding farms, the boar studs are the most pivotal sites of biosecurity.

My twelve companions on this tour might be best glossed as Pod Managers. They were geneticists, nutritionists, veterinarians, and executives who fill their working days on farm tours analyzing the most problematic strands of the Herd within Dover Foods' system, usually those undergoing a disease event. Inspecting the interiors of barns do enable forms of diagnostics - perhaps the farmworkers were being slack in cleaning farrowing rooms — but much of the Pod Managers' time is spent driving in a cramped van while diagnosing the external or environmental causes of symptoms witnessed on a set of pigs. Such banter revealed a hard-earned familiarity with the Great Plains' ecology as they described how terrain gradations around a given site might explain disease rates, or how an area's wind patterns could seam microbial networks across barns. They learned, for example, that national data on the spread of disease in highly wooded areas such as North Carolina did not apply to the Midwestern terrain. Where I saw flat grain fields, they saw invisible traces of porcine life totally, yet differentially, spread over an uneven landscape.

Highly respected in the pork industry, this group of managers came together after working separately in corporations across the United States, Chile, the Philippines, England, and Canada. Graham, the head of live-production operations, grew up in North Carolina during the first wave of industrialization in the late 1980s. A working-class kid unable to afford college, and not academically inclined, he started out as an entry-level power washer in hog barns and jumped across corporations as he moved up the ranks. Barry, a senior regional manager, went to agricultural college in the 1980s, planning to take over his parents' beef cattle 
ranch. He soon found his family bankrupt in the midst of a farm crisis. Recruited by a pork corporation, he became a global expert in emergent methods of artificial insemination. Gregory was the company's lead veterinarian. Though initially skeptical, he found himself enjoying the relative stability of corporate agribusiness after years of treating pigs in his private practice during farm crises. He recounted walking into a private barn where emaciated, dying pigs had not been fed for days because their owner was too broke to cover the cost of feed.

These men entered the corporate pork industry under conditions not purely of their choosing, but they also strove to create the most profitable and ethical pork corporation possible in an industry with very low margins of return. Though they had become tight-knit over the years, they were not unified in their beliefs. The Pod Managers - especially those trained in the veterinary mission — would often bicker behind each other's backs over who was more "health-centered" versus "production-centered." During the 1990s, they mainly worked apart in different corporations during what they called Growth Mode, when corporations rapidly expanded barn sites before states placed moratoria on new hog farms and competition that would start to bite into profit margins. The current goal, in Polishing Mode, was to maximize porcine value in the vertically integrated system, searching, as they often put it, "now that there's no more low-hanging fruit," to "find new money" in the porcine species. The promise of vertical integration is twofold: it aims to produce a more standardized porcine body to increase the value of the species in global wholesale markets, while attempting to make more pigs per sow (Blanchette 2013).

Yet the grim sights on these farm tours hinted at the ways that vertical integration's promises of total control over porcine life remained unfulfilled, reflecting how life constitutes an excessive entity that cannot ever be standardized (cf. Hinchcliffe and Ward 2014; Allen and Lavau 2015). Growth Mode's end occurred at the same time that, as another veterinarian put it, "the health system started to erode." One example of the many endemic illnesses afflicting the modern hog is Porcine Reproductive and Respiratory Syndrome (PRRS). It first emerged globally during the intensification of pork production in the late 1980s (Cho and Dee 2006), it disproportionately affects fragile lean pigs (Rich 2008), and it tends to get lodged in confinement barns (Harris 2004). The industry frames PRRS as its most economically significant illness (prior to PEDv), costing U.S. farmers some $\$ 560$ million per year (Johnson et al. 2012). Though PRRS weakens pigs' immunity, it rarely kills them directly. It causes miscarriages in gestating sows and decreases weight gains in market swine. PRRS is an economic disease- 


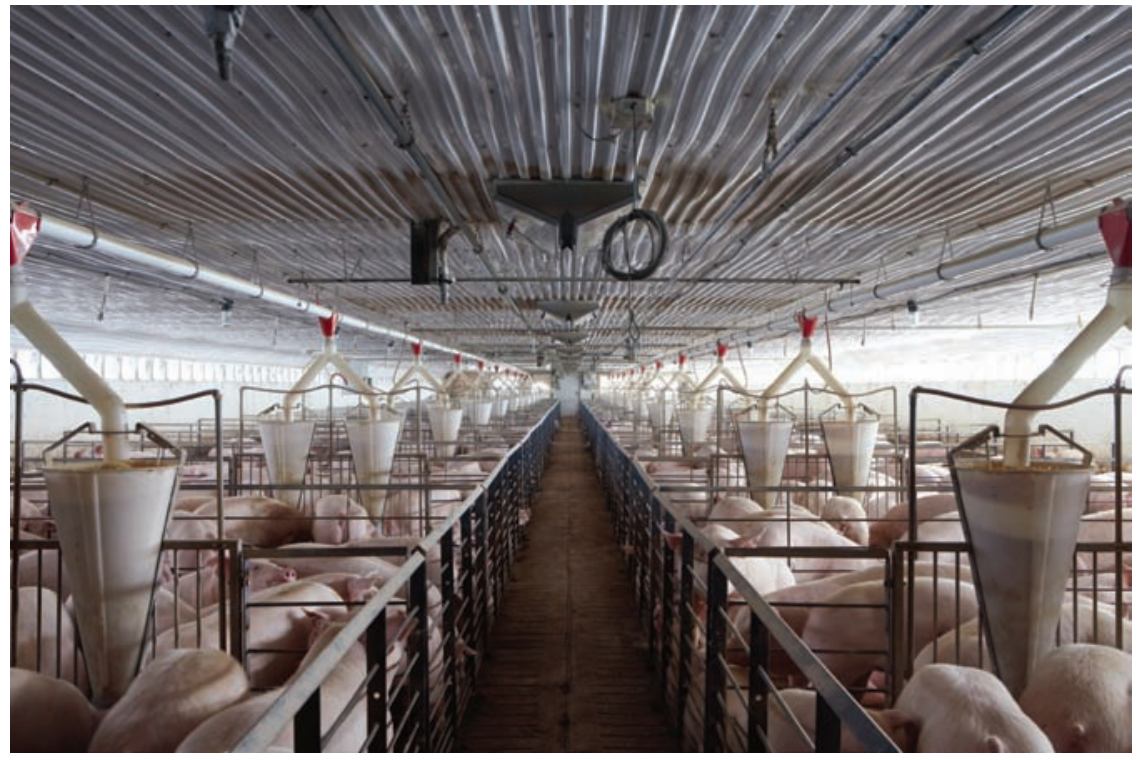

Figure 4. Grown hogs in a confinement barn, shortly before being transported to the packing plant for slaughter. Photo by Sean J. Sprague.

we might call it a species disease- because it throttles the Herd's vital proliferation. A couple of Pod Managers lamented how the severity of outbreaks can increase as the concentration of animals deteriorates the ecology, resulting in what they called an "aging of the Herd" that worsens with time as strains of viruses mutate and compound with other illnesses. In these conditions, the demand to make the Herd's sows into corporate life forms (Cooper 2008) - expected to continually increase in numerical productivity, increasing in biocapitalist growth in spite of microbial aging-proves vexing even to managers who ostensibly control the system. As one veterinarian declared in frustrated opposition to my insistence on their agency: "No. The Herd is everything [that is, it is bigger than them]. We are slaves to the Herd."

Such, at least, is the Herd's-eye view of disease rendered into a shifting statistical portrait of its effect on animal reproduction. The daily tours of barns reminded everyone of a more visceral sense of pig disease as we walked past rows of animal cages, fixated on symptoms that might indicate PRRS or some other illness. One day the veterinarians would point at coughing animals, or hogs' rumps streaked brown with scours, or diarrhea. On another, piglets were emaciated with a condition called "suck-in," their stomachs taut against their ribs, or "thumping”- a respiratory condition that makes pigs loudly wheeze. Low-level farm 
managers, working extra hours to handle an outbreak, would nervously recount how many "aborts" (miscarriages) they found on the floor during morning inspections. During hundred-mile drives across barn sites, Pod Managers often discussed animal scientists' research into the spread of hog illness, revealing how porcine materials saturate everything. Scott Dee et al. (2002) have conducted experiments that demonstrate how viruses such as PRRS can blanket a region, creating an "area spread." It can infect pigs via wind transmission, through mosquitoes, semen, blood, saliva, feces sprayed as fertilizer, rodents, workers' clothing, trucks that ship pigs, and in delivery containers. As a Dover manager informed me, "We don't know how productive the genetics of our sows might be. We can't see the pure healthy animal."

Invocation of academic research on disease, however, would often lead to disagreement over managers' own values of efficiency, animal welfare ethics, culpability, and limits to containing the Herd's degradation. In the mid-2000s, Dover tried to eradicate PRRS. Beyond the economics, most managers agreed that eliminating PRRS was an ethical imperative given how it causes pig illness. They invested millions of dollars into cleaning barns, relocating farm sites, installing so-called biocurtains on barn ducts, and initiating new biosecurity protocols. For three months, there were no reports of PRRS symptoms. The disease then broke out in genetic multiplier barns - the nucleus of vertical integration, where they make the sows that then make meat animals for commercial slaughter. The vector of transmission was tracked to a hobbyist's show pig a few miles upwind. Once the genetic heart of the operation was infected, the disease spread through the downstream barns with crippling force, because the new lines of pigs had no inbuilt immunities. Since this time the Pod Managers, like most corporations, have pursued an endemic "PRRS-positive" production strategy. They manage and quarantine the virus as it appears in a barn, stabilizing its quantitative effects in terms of seasonal pig output and building immunities in the Herd as a whole. $^{16}$ The veterinarians also became production-centered, perhaps partially leaving behind the health-centered perspective learned in school. The totalizing quality of disease appeared to lead to the adoption of a Herd-based cost-benefit approach to health, one that frames decreases in sow productivity as the vital symptom.

\section{MAKING BIOSECURE SUBJECTS}

Amid this sense of invisible but dense porcine material, boar studs offer onlookers a much more disciplined aesthetic of life and labor. The boar stud is 
an icon of biosecurity; it is a destination for company investors and wholesalers hoping to witness a variation-free architectural image of precise control. Isolated from human activity by twenty miles and the dividing line between two states, there are no lights on the horizon save for the stars. The building is nested within a thirty-foot perimeter of gravel that tamps out plant life. Enclosing this dead zone is a twelve-foot-high, password-locked fence topped with barbed wire. Even the specially selected species of grass that extends beyond the perimeter is maintained to ensure that there are no weeds to attract rodents.

Nonetheless, these aesthetics of security could be described as a spectaclea performance - because the interiors of barns always teem with nonporcine life. Mice dart out to nibble at pigs' feed, and birds line the perimeters of the manure lagoons. Clouds of mosquitoes hover over the animals during warm months, leading to a measurable summertime decrease in slaughterhouse carcass yields from cutting out the bites on skin. I once saw a fire extinguisher encased in what appeared to be a centimeters-thick weave of grey cobwebs. I checked its date, thinking that it had not been changed for a decade. It had been inspected a few months earlier. This spectacular aspect, however, does not mean that on-farm biosecurity is futile. Its performativity is the overarching point.

As a Food and Agriculture Organization (2010,3) publication for hog farms states, agricultural biosecurity is not only "the implementation of measures that reduce the risk of the introduction and spread of disease agents" but also "requires the adoption of a set of attitudes and behaviors by people to reduce risk in all activities involving . . . animals and their products." These aesthetics are what we might call doubling biosecurities. They excise "disease agents" while demanding workers' psychosocial recognition of their corporeal intimacy with the animal. This doubling mode of biosecurity becomes logical in sites where PRRS and other diseases are rampant, when the scale of production is so large-and human interaction outside of work so unruly — that it leads managers to see working humans' socialities as reservoirs for animal illness.

Doubling biosecurities abound, from the tedium of power-washing farrowing rooms to the human food allowed in barns. The standard process of showering in and out at barn sites constitutes the prime example, a ritual that I would repeat as many as six times per tour. Workers undress on "the dirty side" and put their clothes into a bank of lockers. The first step is to take a regular shower, washing the body and hair using liquid company soap from a dispenser on the wall. The second is to scrub unusual parts of the body such as the fingernails, the ear's curves, and nostrils. Cotton swabs are available for drying these body parts on 
"the clean side," prior to donning the company's socks, brief-style underwear, Tshirts, blue coveralls, and rubber boots. This five-minute ritual made me question my actions during the past hours, recalling the animals and people that I had met. I initially felt paranoid about whether missed flecks would be responsible for pig illness, once confessing that I had been with workers the previous evening.

Such accounting of one's corporeality is more pedagogical than it is enactive of actual biophysical security. It aims to turn workers into biosecure subjects who monitor their habitus despite managers' inability to watch their actions at all moments, such as when they are in the shower. By making workers fear their potential to harm animals, learned from past experiences of a disease outbreak in a barn, the shower enlists moral subjects to work with the Herd. Or, these biosecurities enable managers to maintain their identity as statistically productioncentered by improving the output of the pigs that they confront abstractlyworking on the Herd-while turning workers into health-centered subjects deemed culpable for the suffering of the actual pigs that they work with in a tactile manner. ${ }^{17}$ Biosecurity protocols create new kinds of classes of people, tethered to concrete manifestations of the vertically integrated pig-boars, sows, growing hogs, or carcasses — and fixed in single barn sites, while letting Pod Managers dwell outside any single type of animal and work on the species as a whole.

Managers have developed a series of sensory technologies that enable them to powerfully experience a species in its abstract entirety, and which make evident the need for the off-farm biosecurity protocols that initiated this essay. On farm tours, as we departed the boar stud and moved across sites in the van, we were performing a (managerial) form of biosecurity, which I once heard someone call "walking the pods." Pod Managers are the only people in the factory farm who can travel across distinct types of hog farms. A production manager, in distinction, might manage six sow farms but would not set foot in any growing barns. Senior managers work on the Herd because they are not locked into working with only one strand or type of pig; they practice a management of the pig in all of its possible expressions or manifestations, of a species in potentia. A Pod consists of a lineage of all animals from genetic sows (that make sows), to commercial sows (that make meat animals), to piglets, to hogs for the market. The Pod (also known as a genetic flow) is a genetic grouping or family of pigs that moves through predetermined sets of barns as the flow grows in weight and age.

Managers begin their tours at a boar stud because these sites sit at the apex of the so-called Biosecurity Pyramid through which Pod Managers organize their 
means of safely monitoring and physically entering a strand of the Herd without introducing disease. Managers cannot have contact with pigs in any form lower on the pyramid - commercial sows, piglets, grown hogs, carcasses - for one to three days before entering a boar stud, genetic sow farm, or otherwise moving up. They can, however, move down the pyramid in a single day if they stay in the same Pod. The system is designed so that a given Pod will (ideally) never make contact with other lineages of pigs, especially not in forms mediated by human bodies. The set of barns through which a given Pod moves (or "flows") can also be changed over time, such as when a given barn or region of the Great Plains landscape appears to be saturated with disease.

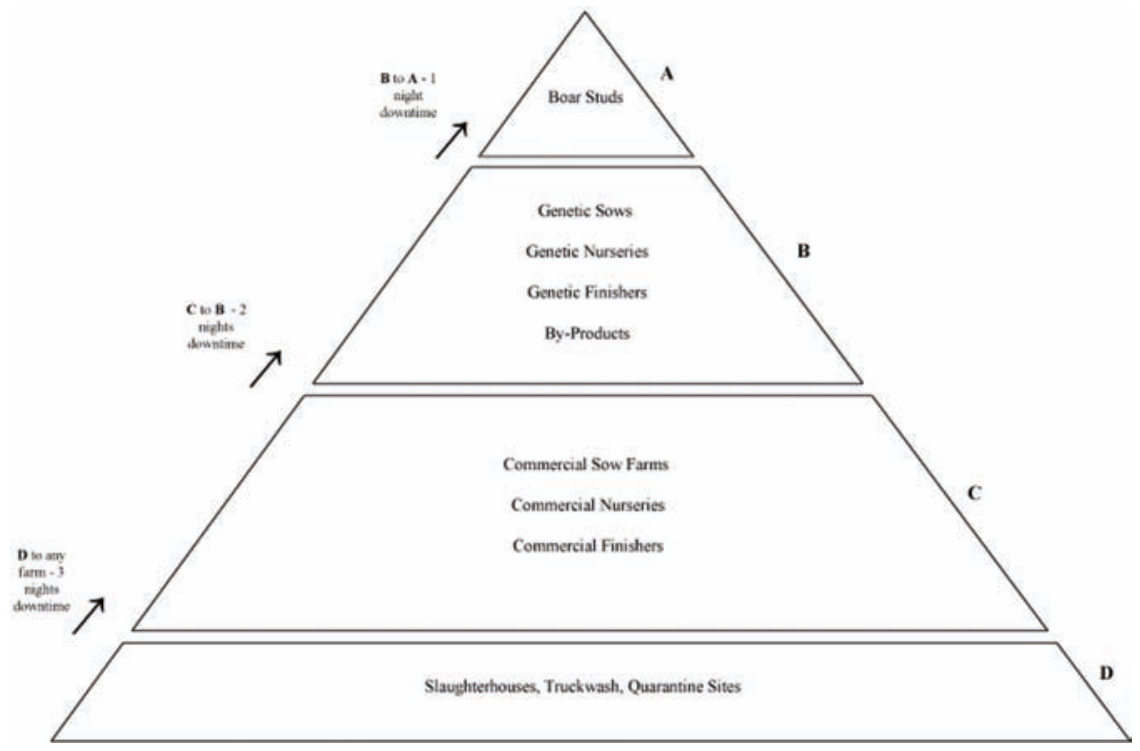

Figure 5. The Biosecurity Pyramid, an example of a planning document used to manage movements through the Herd. On any given week, it is updated to denote the farms currently under quarantine. Illustration by Alex Blanchette.

These are technologies for translating statistical impressions of the Herd into embodied perception as managers "walk [down] the Pods" by inspecting conditions across sections of a genetic flow in a day. When managers walk the Pods, they imagine themselves as moving down the spatiotemporal flow of life to physically witness all the historical conditions that a lineage of pigs has experienced. The model requires standardized control of minute conditions over time. It presumes that young pigs downstream the flow in, say, growing barn \#239 once experienced identical microbial and environmental conditions in upstream parts of the 
flow with their maternal sows in breeding barn \#10. The essence of the Pod is that it enables managers to isolate variables outside the Herd's genetics - focusing on all of the animate and inanimate beings that make up fleshly hogs in the actual everyday. The model maintains a sense of static temporality such that pigs in Pod \#4, growing at day 108 of their lives, are identical to those of the same Pod \#4 at day 32. Since trucks move these pigs across similar spatial ecologies, geographies, and sets of barns, managers hypothesize that if a barn of pigs started exhibiting poor performance numbers in terms of, say, converting feed into flesh at day 92, then the piglets at day 14 will also develop identical problems unless managers intervene and diagnose problems in the environment that these pigs will flow through on day 92.

The Pod constitutes an organizational device to interpret the microbial ecology of the Great Plains, because it frames all external forms confronting pigsbarns, workers, wind patterns, terrain gradations, or perhaps even towns on trucking routes - as inputs affecting the lineage of pigs trickling down from the upstream genetic sows. As a flow moves through space, managers can see it as filtering all the material things it confronts. Moreover, the need for the standardization of all forms of life that orbit around the barns is embedded into this mode of multispecies organization. Conditions across the Biosecurity Pyramid and the flow must remain identical for managers to travel down Pods and assume that pigs on day 14 will experience identical conditions on day 92, or that Pod Managers' bodies are not carrying new diseases from upstream farms into downstream barns. Increasing degrees of standardized control over time- over life and labor - is the condition on which the model depends.

These tethered sensory technologies - the Herd, the Pod, and the Biosecurity Pyramid - enable workplace practices that materialize industrial animality as a form of life in potentia. Recall, as one manager put it earlier in this essayin distinction to old-time farmers who managed individual animals - "our mentality is that we manage the Herd.” This abstract industrial animality temporarily manifests as forms of appearance in boars, sows, piglets, and grown meat pigs in a continuous flow of becoming that is absorbing the materialities of a region. One result of such embodied ecological perception of animal life is that it becomes clear how pigs are no longer raised in barns alone, but across the region as a whole - including, potentially, in gas stations, churches, or Cesar's family living room. Indeed, such a mentality allows them to perceive a kind of swine that exists as a theoretical abstraction and an animating vitality outside of concrete forms of animal appearance such as boars, at the same moment that it offers a 
class-based mode of ecological perception arguably required to sustain the modern pig and its diseases. This is a particular kind of capitalist animal species. It undergirds regional policies, but it is only perceptible to those managers who (unlike workers) are not tethered to working with a single type of hog. Its effect is to license managers to speak for the industrial pig as a whole, and to interpret a region through it, while illustrating the powerful forms of knowledge that underlie any act of trying to materialize, sense, and value a species in its entirety.

\section{CONCLUSION: PORCINE WORLDS}

The standard notion of biosecurity is, at root, founded on a fantasy of separation — of "enclos[ing] humans and animals in specific, sterile, and segregated spaces" (Lezaun and Porter 2015, 100). In this essay, I have suggested how the factory farm pushes beyond logics of hog confinement to the point where managers feel they have to learn how to sense industrial animality as copresent with and defining every facet of a region, including workers' bodies. Pursuing such a project of speciation - tracing the postanthropocentric making and ranking of species - has been my central concern in this essay, unpacking the forms of species-level managerial work that allow the industrial pig's vitality to gradually mediate a region's ecology, class relations, and laboring subjectivities. Unlike anthropocentric public health efforts that aim to control animality within human worlds - that police unruly animals' and insects' movements to buttress a hope for a purely human biosociality (see Lowe 2010; Nading 2012)—what is striking is the partly enacted fantasy that underlies this corporate regime: it signals an impossible desire to confine humanity in animal worlds. This process is not so much a matter of regional dehumanization as it is, in ways that remain hard to articulate given the tendency to grasp agrocapitalist projects such as the factory farm in terms of anthropocentric domination, a matter of reading and controlling territory and populations through the porcine species.

In closing, then, I want to return to the troubling core of Cesar's family story - that the industrial pig somehow exists in his home - that jolted my settled sensibilities concerning the factory farm. In theory, capitalist agriculture is supposed to produce carnal abundance with minimal space and effort. Like all industrial projects, it concentrates labor and land use - even if, as critics are quick to point out, its externalities saturate the globe by polluting waterways and the atmosphere (Weis 2013; Wallace and Kock 2012). This efficiency is why it is deemed ethically necessary to feed the world in the face of growing populations. This essay has suggested in response that the factory farm is not a straightforwardly 
anthropocentric project of reducing labor and land at the expense of increasing harm to animals and the environment. The species forms that managers are summoning in the wake of the waning vitality of the modern hog-perhaps as a feature of lively capital more generally (see Dumit 2012) — are better described as devices that convert human activities into labor and that reveal how the industrial pig saturates an ecology. They mark the ongoing creation of a being whose sustenance requires emerging quantities and qualities of work by managers and workers alike. Once the human becomes sensible as a reservoir of disease-a necessary threat to the porcine species-forms of mundane sociality, such as starting a new relationship, have the potential to be deemed bio-insecure, changing into a form of labor in service of maintaining fragile animal vitalities.

Many potent ironies exist here: the anthropogenic creation of a postanthropocentric landscape; some managers' species ontologies restricting their own autonomy; the industrialization of life maintained through increasing amounts and forms of (albeit unpaid and underrecognized) labor; and, most obviously, the fact that it is individual pigs who are most burdened by their species' ascent to the position of a region's dominant organism. But in a zone marked by such contradictions - and perhaps in other parallel landscapes given over to making capitalist species - what seems clear is the need for a language that goes beyond the currently isolated political imaginaries of animal or worker rights, once the health and liberty of individual pigs and people are affected by the state of vitality in which they are mutually embedded.

\begin{abstract}
This article examines microbial ecologies and industrial ontologies as they unfold in the animal worlds created by the American factory farm. Based in a hundred-mile radius region of the U.S. Great Plains - where some seven million hogs are annually manufactured from prelife to postdeath - it unpacks agribusiness managers' varied modes of socio-ecological intervention once porcine overproduction causes disease to breach the indoor spaces of confinement barns. Maintaining the genetic potency of modern industrial animals requires managers to appraise how the pig has become intertwined with wind patterns, terrain gradations, and humanity. One result is that corporations are enacting intimate biosecurity protocols in workers' domestic homes, a move that frames human sociality as a reservoir sheltering porcine disease. Workers are reimagined as a threat to the vitality of industrial hogs in ways that subtly alter the value of human livelihood and autonomy in this region. To situate how rural work became ambiguously posthuman, this essay develops a political economy of speciation. It inhabits managers' abstract technologies that allow them to become attuned to the industrial pig as a fragile and world-defining species in need of new
\end{abstract}


types of laboring subjectivity, while analyzing the postanthropocentric politics of class and value in a zone reorganized around forms of capitalist animality. [labor; animals; social class; anthropocentrism; biosecurity; industrial agriculture; United States]

\section{NOTES}

Acknowledgments Primary thanks are owed to the many residents of the town of Dixon whose insights and work are the basis of this article. This essay was initially developed for the Anthropology and Environment Society's 2011 Rappaport Student Prize panel, and I thank Lisa Cliggett for organizing that forum. A wide range of comments and critiques - both sustained and off-the-cuff-took the writing in new directions. I thank James Brooks, Jessica Cattelino, Summerson Carr, Tatiana Chudakova, Judith Farquhar, Kathryn Goldfarb, Bridget Guarasci, Elayne Oliphant, Natalie Porter, Gabriel Rosenberg, Caroline Schuster, Rosalind Shaw, Ageeth Sluis, Brad Weiss, Kara Wentworth, and most especially Joseph Masco. Comments by three anonymous reviewers, the Cultural Anthropology editorial collective as a whole, and Cymene Howe in particular, greatly strengthened the article. The research and writing was supported by the Wenner-Gren Foundation, the National Science Foundation, and the School for Advanced Research. Thanks also to Sean J. Sprague for his company and significant photographic skills, and to the Wenner-Gren Foundation's Osmundsen Initiative for providing funding for this visual dimension of the project.

1. All company and place names in this essay are pseudonyms, intended to provide a measure of anonymity to individuals in the four pork corporations where I conducted research. I am unable to specify with precision the exact locale where most of my fieldwork took place, as the five largest pork corporations in the United States are each centrally located out of a single state. Colorado, Illinois, Iowa, Kansas, Missouri, Oklahoma, Texas, and Utah all contain major corporate pork installations that resemble the operations I will be describing in this article.

2. The bulk of this conversation occurred in Spanish, but shifted to English as technical workplace terms such as biosecurity became the subject of discussion. This was the norm on farms, where the primary spoken languages were Spanish or K'iche, mixed with the English farming phrases taught during training. At the time of my research, a complicated racial division of labor extended across the factory farm's various worksites. For example, the people who I encountered in breeding were of Mexican, Guatemalan, or Cuban descent, while migrants from Burma tended to staff the slaughterhouse's overnight sanitation shift. With a few exceptions, the most senior managers tended to be white and United States-born, and they spoke English as their primary language.

3. Public health researchers have started to find evidence that hog farmworkers can carry antibiotic-resistant bacteria on their bodies for several days in spite of showering protocols (Nadimpalli et al. 2014). This form of human-to-human infection is considered rare and is labeled "tertiary exposure" in the pork industry biosecurity literature, as distinguished from the relatively more common forms of hog-to-hog (primary) or hoghuman-hog (secondary) exposure (Morrow and Roberts 2002). But this biosecurity protocol is not unique to Dover Foods. For example, an Australian biosecurity organization suggests that all hog farm employees sign a declaration that includes, among other stipulations, a pledge that they will not live with other animal farmworkers (AHA 2012).

4. There is no formal rule, to my knowledge, dictating that managers across different nodes of porcine life and death cannot socialize. There remain situations at work - such as planning meetings - when some managers must be copresent. Still, this burgeoning consciousness and rule-of-thumb was further made clear to me when a couple managers expressed uncertainty about how (or whether) to interact with my embodied self, as a researcher who spoke with different social classes and spent time in multiple firms. 
5. See Timothy Choy and Jerry Zee (2015) for an account of an anthropology of suspension wherein beings are diluted, intermingled, and held together through the shared medium of the atmosphere. The term atmospheric attunement was first used by Kathleen Stewart (2011).

6. Nor is it unprecedented in animal agriculture. In her remarkable study of small-scale slaughterhouses in Minnesota, Kara Wentworth (pers. comm.) describes how farming families would strip off clothes outside their homes and between house and barn after attending community events such as high school basketball games, church, or 4-H competitions, where they would have encountered other agriculturalists.

7. For this reason, I characterize the factory farm as ambiguously postanthropocentric: neither fully anthropocentric in its local realization on the ground, and quite obviously not purely porcine-centric given that it is a matter of making life and death for human consumption.

8. Emily Yates-Doerr $(2015,309)$ has called for a multispecies scholarship that rejects the taxonomic urge to preemptively classify things into fixed natural categories, and that instead illustrates the ongoing work of enacting species needed to make "an occurrence of coherence situated amid ever-transforming divisions and connections."

9. While farmers have called groups of owned hogs a herd for centuries, I refer to the Herd as an organizational technology that is specific to industrial animal production.

10. In a parallel way, Timothy Pachirat (2011) vividly renders how each worker in the slaughterhouse experiences animal death differently based on their position on the line.

11. See Henry Buller (2013) for an insightful philosophical analysis of farm animal massification, which focuses on how seeing in mass affects off-farm apparatuses such as animal welfare science.

12. My focus on the workplace division of labor leads me to emphasize class as an analytic in this article. But one could just as easily characterize this as a process of racialization through industrial animality. Those who are hired to "work with" the Herd are almost all people of color, while those who are employed to abstractly "work on" the Herd tend to be white.

13. See Javier Lezaun and Natalie Porter (2015) for a different - arch-anthropocentrickind of privatization of public biosecurities through the development of transgenic animals that would not shed disease and would require no modification of contemporary human activities.

14. See Joseph Masco (2014) and Carlo Caduff (2014, 115) for important analyses of what the latter terms biosecurity's infelicity, or how "security . . . has itself become a significant source of insecurity."

15. In North Carolina, for example, meatpacking corporations tend to contract with ostensibly independent farmers to raise pigs for the slaughterhouse. This limits the amount of land, buildings, and supply of labor that the corporation must supply. See Ronald Rich $(2003$, 2008) for a detailed study of the ways that contracting played out in the state of Illinois, as well as how the biological fragility of lean hogs served as the impetus for certain indoor-confinement technologies and forms of production contracts.

16. Steve Hinchliffe (2014) and Steve Hinchcliffe and Kim J. Ward (2014) discuss building immunities in hogs and managing endemic illnesses, noting how supposedly disease-free barns would only result in the emergence of new illnesses.

17. While disturbing videos of workers beating animals have been picked up by the media to create the impression that employees are alienated from and indifferent to pigs, I found the opposite. Workers would often go to incredible lengths - almost jarringly so - to intimately heal pigs with which they worked (see Blanchette 2013, chapter 3).

\section{REFERENCES}

Allen, John, and Stephanie Lavau

2015 “'Just-in-Time' Disease: Biosecurity, Poultry and Power.” Journal of Cultural Economy 8, no. 3: 342-60. http://dx.doi.org/10.1080/17530350.2014. 904243 
Animal Health Australia (AHA)

2012 “Employee Biosecurity Declaration Template," accessed August 9, 2015. http:// www.farmbiosecurity.com.au/wp-content/uploads/2012/11/Employee-

Biosecurity-Declaration-Template.pdf

Bennett, Jane

2010 Vibrant Matter: A Political Ecology of Things. Durham, N.C.: Duke University Press. Blanchette, Alex

2013 "Conceiving Porkopolis: The Production of Life on the American 'Factory' Braverman, Harry

Farm." PhD dissertation, University of Chicago.

1974 Labor and Monopoly Capital: The Degradation of Work in the Twentieth Century. New York: Monthly Review Press.

Buller, Henry

2013 "Individuation, the Mass, and Farm Animals." Theory, Culture, \& Society 30, no. 7-8: 155-75. http://dx.doi.org/10.1177/0263276413501205

Caduff, Carlo

2014 "On the Verge of Death: Visions of Biological Vulnerability." Annual Review of Anthropology 43: 105-21. http://dx.doi.org/10.1146/annurev-anthro-102313030341

Cassidy, Rebecca, and Molly Mullin, eds.

2007 Where the Wild Things Are Now: Domestication Reconsidered. Oxford: Berg.

Cho, Jenny G., and Scott A. Dee

2006 "Porcine Reproductive and Respiratory Syndrome Virus." Theriogenology 66, no.

3: 655-62. http://dx.doi.org/10.1016/j.theriogenology.2006.04.024

Choy, Timothy, and Jerry Zee

2015 “Condition - Suspension.” Cultural Anthropology 30, no. 2: 210-23. http://dx. doi.org/10.14506/ca30.2.04

Collier, Stephen J., Andrew Lakoff, and Paul Rabinow

2004 "Biosecurity: Towards an Anthropology of the Contemporary." Anthropology Today 20, no. 5: 3-7. http://dx.doi.org/10.1111/j.0268-540X.2004.00292.x Cooper, Melinda E.

2008 Life as Surplus: Biotechnology and Capitalism in the Neoliberal Era. Seattle: University of Washington Press.

Davis, Mike

2007 The Monster at Our Door: The Global Threat of Avian Flu. New York: Holt Paperbacks.

Dee, Scott, John Deen, Kurt Rossow, Carrie Wiese, Satoshi Otake, Han Soo Joo, and Carlos Pijoan

2002 "Mechanical Transmission of Porcine Reproductive and Respiratory Syndrome Virus through a Coordinated Sequence of Events during Cold Weather." Canadian Journal of Veterinary Research 66, no. 4: 232-39. http://www.ncbi.

Dumit, Joseph nlm.nih.gov/pmc/articles/PMC227010/

2012 "Prescription Maximization and the Accumulation of Surplus Health in the Pharmaceutical Industry: The_BioMarx_Experiment.” In Lively Capital: Biotechnologies, Ethics, and Governance in Global Markets, edited by Kaushik Sunder Rajan, 45-92. Durham, N.C.: Duke University Press.

Eisenstadt, Marpie

2014 “Deadly Pig Virus Puzzles Scientists with Rapid Spread.” Syracuse.com, May 12. http://www.syracuse.com/news/index.ssf/2014/05/deadly_pig_virus_

Fearnley, Lyle puzzles_scientists_with_rapid_spread.html

2015 "Wild Goose Chase: The Displacement of Influenza Research in the Fields of Poyang Lake, China.” Cultural Anthropology 30, no. 1: 12-35. http://dx.doi. org/10.14506/ca30.1.03 
Food and Agriculture Organization of the United Nations (FAO)

2010 "Good Practices for Biosecurity in the Pig Sector: Issues and Options in Developing and Transition Countries." Animal Production and Health Paper, Franklin, Sarah no. 169. http://www.fao.org/docrep/012/i1435e/i1435e00.htm

2007 Dolly Mixtures: The Remaking of Genealogy. Durham, N.C.: Duke University Press. Genoways, Ted

2014 The Chain: Farm, Factory, and the Fate of our Food. New York: HarperCollins.

Gray, Gregory C., Troy McCarthy, Ana W. Capuano, Sharon F. Setterquist, Christopher

W. Olsen, Michael C. Alavanja, and Charles F. Lynch

2007 "Swine Workers and Swine Influenza Virus Infections." Emerging Infectious Diseases 13, no. 12: 1871-78. http://wwwnc.cdc.gov/eid/article/13/12/06-1323_ article

Haraway, Donna J.

2008 When Species Meet. Minneapolis: University of Minnesota Press.

Harris, Hank

2004 "PRRS from 30,000 Feet." Swine Health Report, fall: 6-8.

Helmreich, Stefan

2008 “Species of Biocapital.” Science as Culture 17, no. 4: 463-78.

Hetherington, Kregg

2013 "Beans before the Law: Knowledge Practices, Responsibility, and the Paraguayan Soy Boom." Cultural Anthropology 28, no. 1: 65-85. http://dx.doi.org/10. $1111 /$ j.1548-1360.2012.01173.x

Hinchcliffe, Steve

2014 "More Than One World, More Than One Health: Re-configuring Interspecies Health.” Social Science \& Medicine, no. 129: 28-35. http://dx.doi.org/10.1016/ j.socscimed.2014.07.007

Hinchcliffe, Steve, and Kim J. Ward

2014 "Geographies of Folded Life: How Immunity Reframes Biosecurity." Geoforum 53: $136-44$.

Holmes, Seth

2013 Fresh Fruit, Broken Bodies: Migrant Farmworkers in the United States. Berkeley: University of California Press.

Johnson, Colin D., John W. Mabry, James B. Kliebenstein, and Eric Neumann

2012 “The Impact of PRRS on the Pig Cost of Production." Iowa State University Animal Industry Report AS 651, ASL R2045. http://lib.dr.iastate.edu/ans_air/vol651/ iss $1 / 71$

Kirby, David

2010 Animal Factory: The Looming Threat of Industrial Pig, Dairy, and Poultry Farms to Humans and the Environment. New York: St. Martin's Press.

Kirksey, Eben

2014 The Multispecies Salon. Durham, N.C.: Duke University Press.

Kohn, Eduardo

2013 How Forests Think: Toward an Anthropology Beyond the Human. Berkeley: University of California Press.

Lakoff, Andrew

2008 "The Generic Biothreat; or, How We Became Unprepared." Cultural Anthropology 23, no. 3: 399-428. http://dx.doi.org/10.1111/j.1548-1360.2008.00013.x

Lakoff, Andrew, and Stephen J. Collier

2008 Biosecurity Interventions: Global Health and Security in Question. New York: Columbia University Press.

Lezaun, Javier, and Natalie Porter

2015 "Containment and Competition: Transgenic Animals in the One Health Agenda." Social Science \& Medicine, no. 129: 96-105. http://dx.doi.org/10.1016/j. socscimed.2014.06.024 
Lowe, Celia

2010 "Viral Clouds: Becoming H5N1 in Indonesia." Cultural Anthropology 25, no. 4: 625-49. http://dx.doi.org/10.1111/j.1548-1360.2010.01072.x

Masco, Joseph

2014 The Theater of Operations: National Security Affect From the Cold War to the War on Terror. Durham, N.C.: Duke University Press.

Meyer, Stephen, III

1981 The Five Dollar Day: Labor Management and Social Control in the Ford Motor Company, 1908-1921. Albany: State University of New York Press.

Morrow, W. E. Morgan, and John Roberts

2002 "Biosecurity Guidelines for Pork Producers." North Carolina State University Animal Science Facts ANS 02-818S. http://www.ncsu.edu/project/swine_extension/ publications/factsheets/818s.htm

Nadimpalli, Maya et al.

2014 "Persistence of Livestock-Associated Antibiotic-Resistant Staphylococcus aureus among Industrial Hog Operation Workers in North Carolina over 14 Days." Occupational and Environmental Medicine, no. 72: 90-99. http://dx.doi.org/10. 1136/oemed-2014-102095

Nading, Alex

2012 "Dengue Mosquitos Are Single Mothers: Biopolitics Meets Ecological Aesthetics in Nicaraguan Community Health Work." Cultural Anthropology 27, no. 4: 57296. http://dx.doi.org/10.1111/j.1548-1360.2012.01162.x

Pachirat, Timothy

2011 Every Twelve Seconds: Industrialized Slaughter and the Politics of Sight. New Haven, Conn.: Yale University Press.

Paxson, Heather

2008 "Post-Pasteurian Cultures: The Microbiopolitics of Raw-Milk Cheese in the United States." Cultural Anthropology 23, no. 1: 15-47. http://dx.doi.org/10. $1111 /$ j.1548-1360.2008.00002.x

Porter, Natalie

2013 "Bird Flu Biopower: Strategies for Multispecies Coexistence in Việt Nam." American Ethnologist 40, no. 1: 132-48. http://dx.doi.org/10.1111/amet. 12010

Raffles, Hugh

2010 Insectopedia. New York: Pantheon.

Rich, Ronald

2003 "Pigs for the Investors: Commoditization, Differentiation, and Personalism in Illinois Contract Hog Production." PhD dissertation, Southern Illinois University, Carbondale.

2008 "Fecal Free: Biology and Authority in Industrialized Midwestern Pork Production." Agriculture and Human Values 25, no. 1: 79-93. http://dx.doi.org/ $10.1007 / \mathrm{s} 10460-007-9094-9$

Rubin, Gayle

1975 “The Traffic in Women: Notes on the 'Political Economy' of Sex." In Toward an Anthropology of Women, edited by Rayna R. Reiter, 157-210. New York: Monthly Review Press.

Shukin, Nicole

2009 "Transfections of Animal Touch, Techniques of Biosecurity." Social Semiotics 21, Stewart, Kathleen no. 4: 483-501. http://dx.doi.org/10.1080/10350330.2011.591994

2011 “Atmospheric Attunements." Environment and Planning D: Society and Space 29, no. 3: 445-53. http://dx.doi.org/10.1068/d9109 
Strom, Stephanie

2014 "Virus Plagues the Pork Industry, and Environmentalists." New York Times, July 4. http://www.nytimes.com/2014/07/05/business/PEDv-plagues-the-porkindustry-and-environmentalists.html

Sunder Rajan, Kaushik

2012 "Introduction: The Capitalization of Life and the Liveliness of Capital." In Lively Capital: Biotechnologies, Ethics, and Governance in Global Markets, edited by Kaushik Sunder Rajan, 1-41. Durham, N.C.: Duke University Press.

Thaler, Bob

2013 “The Impact of PEDv Continues to Grow." iGrow, December 26. http:// igrow.org/livestock/pork/the-impact-of-pedv-continues-to-grow/

Thu, Kendall M., and E. Paul Durrenberger, eds.

1996 Pigs, Profits, and Rural Communities. Albany: State University of New York Press.

Tsing, Anna

2012 "Unruly Edges." Environmental Humanities, no. 1: 141-54. http:// environmentalhumanities.org/archives/vol1/

Wallace, Robert G., and Richard A. Kock

2012 "Whose Food Footprint?: Capitalism, Agriculture, and the Environment." Human Geography 5, no. 1: 63-83. http://www.hugeog.com/index.php/component/ content/article?id $=211$ : whose-food-footprint-51

Weeks, Kathi

2011 The Problem with Work: Feminism, Marxism, Antiwork Politics, and Postwork Imaginaries. Durham, N.C.: Duke University Press.

Weis, Toni

2013 The Ecological Hoofprint: The Global Burden of Industrial Livestock. London: Zed Books.

White, Richard

1995 The Organic Machine: The Remaking of the Columbia River. New York: Hill \& Wang.

Wolfe, Cary

2009 What Is Posthumanism? Minneapolis: University of Minnesota Press.

2012 Before the Law: Humans and Other Animals in a Biopolitical Frame. Chicago: University of Chicago Press.

Yates-Doerr, Emily

2015 "Does Meat Come From Animals? A Multispecies Approach to Classification and Belonging in Highland Guatemala." American Ethnologist 42, no. 2: 309-23. http://dx.doi.org/10.1111/amet.12132 